\title{
Structure of phytoplankton (Continuous Plankton Recorder and SeaWiFS) and impact of climate in the Northwest Atlantic Shelves
}

\author{
S. C. Leterme ${ }^{1,2, *}$ and R. D. Pingree ${ }^{3}$ \\ ${ }^{1}$ Sir Alister Hardy Foundation for Ocean Science, The Laboratory, Citadel Hill, Plymouth, UK \\ ${ }^{2}$ Marine Biology and Ecology Research Centre, School of Biological Sciences, University of Plymouth, Plymouth, UK \\ ${ }^{3}$ Marine Biological Association of the UK, The Laboratory, Citadel Hill, Plymouth, UK \\ * now at: School of Biological Sciences, Flinders University, Adelaide, Australia
}

Received: 11 September 2006 - Published in Ocean Sci. Discuss.: 27 October 2006

Revised: 25 January 2007 - Accepted: 1 February 2007 - Published: 15 February 2007

\begin{abstract}
All marine organisms are affected to some extent by the movement and thermal properties of oceanic currents. However phytoplankton, because of its small size is most directly coupled to the physical environment. The intense hydrodynamic activity observed in the Northwest Atlantic Shelves Province makes this region especially intriguing from the point of view of physical-biological interactions. In the present work, remote sensed data of Sea Surface Height (SSH) anomalies, Sea-surface chlorophyll $a$ concentrations (SeaWiFS), and Sea Surface Temperature (SST) are used to complement the Continuous Plankton Recorder (CPR) survey that continuously sampled a route between Norfolk (Virginia, USA; $39^{\circ} \mathrm{N}, 71^{\circ} \mathrm{W}$ ) and Argentia (Newfoundland; $47^{\circ} \mathrm{N}, 54^{\circ} \mathrm{W}$ ) over the period $1995-1998$. Over this period, we examined physical structures (i.e. SST and $\mathrm{SSH}$ ) and climatic forcing associated with space-time phytoplankton structure. Along this route, the phytoplankton structures were mainly impacted by the changes in surface flow along the Scotian Shelf rather than significantly influenced by the mesoscale features of the Gulf Stream. These changes in water mass circulation caused a drop in temperature and salinity along the Scotian Shelf that induced changes in phytoplankton and zooplankton abundance.
\end{abstract}

\section{Introduction}

The intense hydrodynamic activity observed in the Northwestern Atlantic Shelves Province (Longhurst, 1998) makes this region especially intriguing from the point of view of physical-biological interactions. This area is under the influence of the cold southward inflow of surface Labrador Sea

Correspondence to: S. C. Leterme

(sophie.leterme@ flinders.edu.au)
Water (sLSW) and the warm northward flow of the Gulf Stream. By sLSW we do not mean Labrador Sea Water that sinks and spreads southwestwards across the Mid Atlantic Ridge with characteristic low salinity and temperature at a depth of $1900 \mathrm{~m}$ in the Bay of Biscay (Pingree, 1973). Rather, the water has surface properties acquired in the Labrador Basin or Newfoundland Shelf (see Griffiths et al., 1981, for IR image). The Gulf Stream flows from the continental slope off Cape Hatteras and travels eastward, meandering until the tail of the Grand Banks (Stommel, 1958). Because of its highly dynamic nature, this environment is a perfect candidate to assess the role of physical-biological interactions in the control of the biological processes by their physical environment.

Frontal and upwelling regions, and their related enrichment processes, are widely acknowledged to be favouring the rapid growth of phytoplankton (e.g. Wyatt and Horwood, 1973 ) as they represent areas where "auxiliary energy" (Margalef, 1978) fluctuates rapidly in space and time (Legendre and Demers, 1984; Legendre et al., 1986). Pingree et al. (1979) also established that eddies have an influence on the transfer and growth of the phytoplankton. More recently, Gonzalez et al. (2001) have shown that mesoscale features are important sources of organic carbon to the pelagic ecosystems in oligotrophic areas and thus greatly influence the plankton community. More specifically, Gulf Stream warm core and cold core rings have been shown to influence surface phytoplankton distributions via the entrainment of the surrounding water masses around and into the rings (Kennelly et al., 1985; Garcia-Moliner and Yoder, 1994; Ryan et al., 1999, 2001). Gulf Stream warm-core rings have also been shown as strongly influencing water mass and chlorophyll distributions along the southern flank of Georges Bank (Ryan et al., 2001; Bisagni et al., 2001). This area is also

Published by Copernicus GmbH on behalf of the European Geosciences Union. 


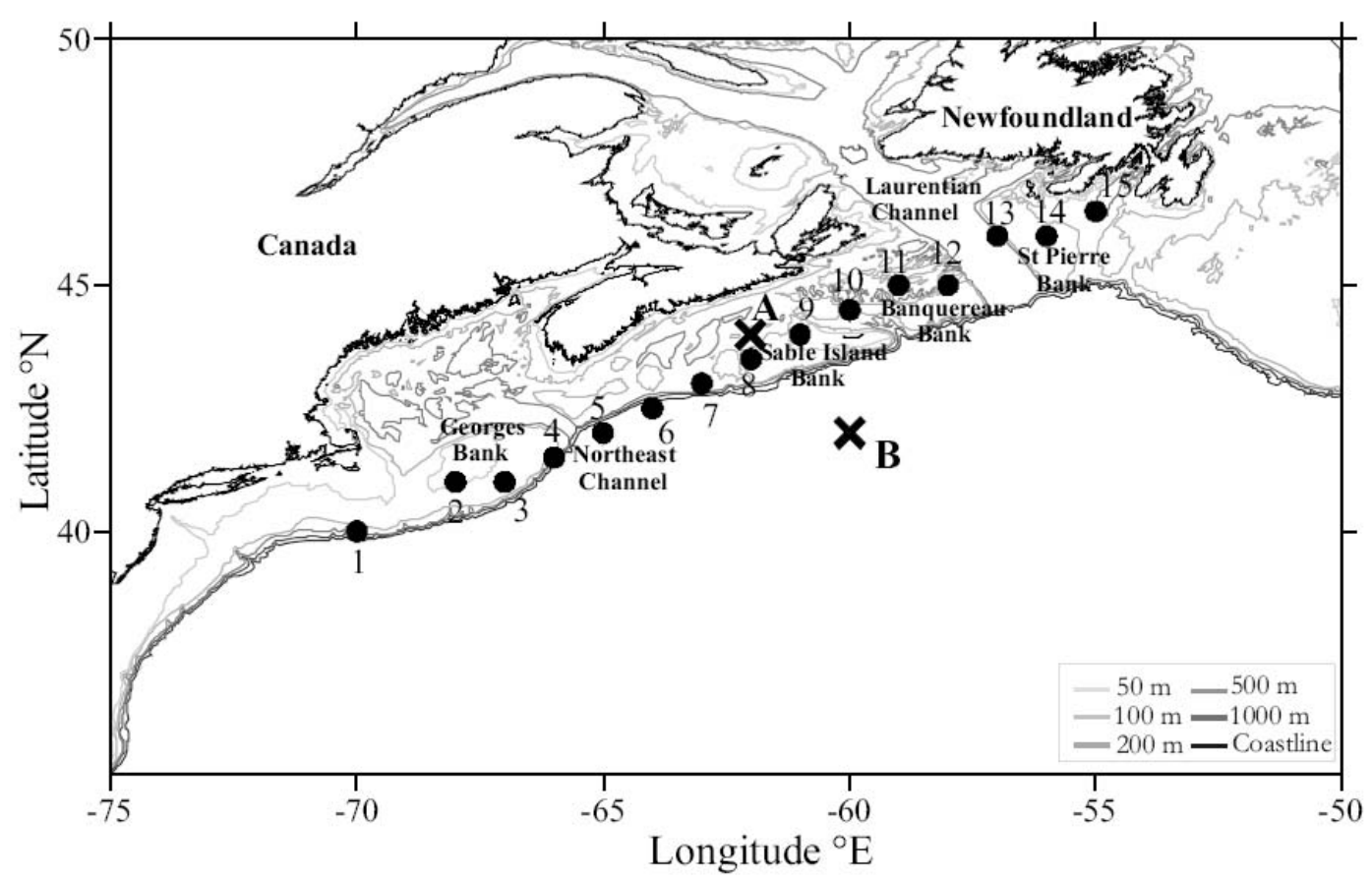

Fig. 1. Topography of the studied area and the 15 stations sampled along the CPR route (black dots). Stations A $\left(44^{\circ} \mathrm{N} 62^{\circ} \mathrm{W}\right)$ and $\mathrm{B}\left(42^{\circ} \mathrm{N}\right.$ $60^{\circ} \mathrm{W}$ ) have been specifically chosen as representative of the shelf area and the open ocean to determine the changes in geostrophic surface flow between them over the period 1992-1998.

under the influence of the North Atlantic Oscillation through modification of the surface and deepwater circulation patterns of the North Atlantic, and more specifically the transport of Labrador Current. The related fluctuations in the inflow of Labrador Subarctic Slope Water (LSSW) along the Scotian shelf have been associated with changes in coastal water characteristics (i.e. SST, salinity and nutrient concentration) and zooplankton abundance (Greene and Pershing, 2000).

Remotely sensed data collected since the late 1970s provide oceanographers with a large volume of information on the state of the surface of the World Ocean. Data provided by infrared sensors collecting information on Sea Surface Temperature (SST), altimeters obtaining anomalies of Sea Surface Height (SSH), and the Sea-viewing Wide Field-ofview Sensor (SeaWiFS) have allowed the analysis of seasonal variations of phytoplankton biomass. It is thus possible to compare biological and physical data obtained simultaneously. The aim of this study is thus to examine the impact of the LSSW changing flow along the Scotian Shelf and the influence of Gulf Stream rings along the George Bank. A specific CPR route (E-route; between Norfolk - Virginia, USA; $39^{\circ} \mathrm{N}, 71^{\circ} \mathrm{W}$ - and Argentia - Newfoundland; $47^{\circ} \mathrm{N}$, $54^{\circ} \mathrm{W}$ ) has then be used to investigate (i) the consistency between PCI and SeaWiFS measurements in this area, (ii) the fluctuations of phytoplankton biomass and its geographical distribution, (iii) the potential links between PCI, SST and $\mathrm{NAO}$, and (iv) the relation between phytoplankton and al- timeter (i.e. Sea Level Anomalies and eddies) over the period 1995-1998.

\section{Materials and methods}

\subsection{Continuous Plankton Recorder}

The Continuous Plankton Recorder (CPR) survey is an upper-layer plankton monitoring program that has regularly collected samples, at monthly intervals, in the North Atlantic since 1931 (Warner and Hays, 1994). The CPR is a highspeed sampler, usually towed at $5-9 \mathrm{~m} \cdot \mathrm{s}^{-1}$, behind voluntary merchant ships at a standard depth of ca $6.5 \mathrm{~m}$ (Hays and Warner, 1993). After the tow, the CPR is brought back to the laboratory for routine analysis. Warner and Hays (1994) have described methods of counting and data processing. Despite the near-surface sampling, studies have shown that this sampling gives a satisfactory picture of the epipelagic zone (Lindley and Williams, 1980). The visual estimation of the total phytoplankton biomass, known as the Phytoplankton Colour Index (PCI), is determined for each sample. This index has four levels of colour from "nil" to "green" ("nil": no phytoplankton, "very pale green": low biomass of phytoplankton, "pale green": medium biomass of phytoplankton, "green": high biomass of phytoplankton). These ordinal values have been assigned numerical values based on the work of Colebrook and Robinson (1965). The CPR survey has 
been sampling continuously a route between Norfolk, (Virginia, USA; $39^{\circ} \mathrm{N}, 71^{\circ} \mathrm{W}$ ) and Argentia, (Newfoundland; $47^{\circ} \mathrm{N}, 54^{\circ} \mathrm{W}$ ) over the period 1995-1998 (Fig. 1). The visual estimation of the total phytoplankton biomass, known as the Phytoplankton Colour Index (PCI), was determined for each of 15 stations along the CPR route, corresponding to the stations most continuously sampled over the period of study (Fig. 1). The Hovmöller diagram of PCI has allowed a comparison of in situ measured structures with those observed from space (i.e. SLA and PCI diagrams) and Sea Surface Temperature (SST).

\subsection{Sea level anomaly}

Sea Level Anomaly (SLA) heights have been measured by the ERS 1/2 and Topex Poseidon satellites since the 22 October 1992 at 10 days intervals. The data have been processed according to Le Traon et al. (1998) with SLA data spatially interpolated to $0.25^{\circ}$ in both latitude and longitude. Data analysis and processing methods of Pingree et al. (1999) were adopted. The SLA is composed of mesoscale structure imposed on seasonal changes with eddy or Rossby wave structure usually dominant. The structures of SLA can be masked by the annual signal which corresponds in part to the rise and fall of the sea surface that arises from the expansion and contraction of the ocean due to its heating up and cooling down with seasonal climatic change. In addition, the SLA is influenced by an annual cycle due to Ocean circulation. Fourier analysis and filtering of SLA in time has been used to determine the periods of dominant structure (i.e. annual signal and longer periods) along the CPR route and has been used to remove the annual signal and any residual mean elevation (which should be zero). Being in a shelf break area, tidal aliasing due to the semi-diurnal tide was removed. SLA have already been shown to allow the tracking of propagating features (Sinha et al., 2004). These data have then been used to estimate the presence and nature of anomalies in the area of study between January 1995 and December 1998. Elevation and depression of the sea surface are plotted on a Hovmöller diagram (i.e. changes of property in space and time).

\subsection{SeaWiFS data}

SeaWiFS is a spectroradiometer that measures radiance in specific bands of the visible light spectrum (Mueller and Austin, 1995). The satellite spectroradiometer offers the possibility of observing and investigating the oceans from a global point of view and provides information on chlorophyll $a$ on a daily, weekly, monthly and annual basis. As phytoplankton contain pigments, they appear as different reflective colours when they are detected by SeaWiFS. SeaWiFS data produced by the SeaWiFS project were obtained from the Goddard Distributed Active Archive Centre under the auspices of NASA. Use of these data are in accord with the Sea-
WiFS Research Data Use Terms and Conditions Agreement. The SeaDAS (SeaWiFS Data Analysis System) software was used to process the SeaWiFS data to final chlorophyll $a$ concentration $\left(\mathrm{C}_{a}\right)$ and was estimated from the ratio of radiances measured in band $3(480-500 \mathrm{~nm})$ and band $5(545-565 \mathrm{~nm})$ according to the following NASA algorithm:

$C_{a}=\exp \left[0.464-1.989 \operatorname{Ln}\left(L_{W M} 490 / L_{W M} 555\right)\right]$

and monthly composite SeaWiFS maps for the North Atlantic were derived. For deriving the 5 year mean seasonal cycles, the SeaWiFS Chl (chlorophyll) $a$ data were spatially averaged over $\pm 25 \mathrm{~km}$ in both latitude and longitude and missing data due to cloud coverage interpolated. The SeaWiFS chlorophyll $a$ concentration data thus obtained allow the study of the structure and seasonality of phytoplankton along the CPR route in the overlapping time window between September 1997 and December 1998.

\subsection{Climatic indices}

Several indices have been developed to quantify the state of the North Atlantic Oscillation, but the most widely used is Hurrell's NAO index (Hurrell, 1995). Monthly indices of the NAO, based on the difference of normalised sea level pressures between Ponta Delgada, Azores and Stykkisholmur/Reykjavik, Iceland, are available since 1865 . In order to take into account the monthly variability, we used monthly-time series of NAO as a climatic index. The Sea Surface Temperature (SST; HadISST 1.1 from the British Atmospheric Data Centre) data were used to provide additional climatic information likely to influence phytoplankton growth and abundance. The longer NAO time series data allow some examination of the temperature or altimeter response to longer period forcing. The cumulative sums method for NAO showed a tendency for periodicity near 2 to 3 years and near 8 years. The present data are insufficient to establish a link with PCI but we note that temperature data in the North Sea sometimes exhibit a 2 to 3 year periodicity and altimeter data can have a significant $\sim 6$ to 8 year response in the northern North Atlantic with marked sea surface elevation gradients in the Northwest Atlantic Shelves and adjacent Ocean region (Pingree, 2005). The winter Index also shows an $\sim 80$ year period with a maximum near 1910 and a minimum near 1950-1960 and further a maximum near 1990. The circulation response to changes in winter NAO Index is discussed in 4.2.

\subsection{Data analysis}

Trends in monthly time series of PCI were examined at each station by calculating Kendall's coefficient of rank correlation, $\tau$, between the series and the time in months in order to detect the presence of a linear trend (Kendall and Stuart, 1966). The relationship between phytoplankton and climate indices was tested through Spearman rank correlation analysis performed at each station between monthly time series of 
Table 1. Spearman correlation analysis between the monthly time series of PCI and SeaWiFS (original data) and between seasonal cycles of PCI and SeaWiFS over the period 1997-1998. *5\% significance level.

\begin{tabular}{lcc}
\hline Stations & Original data & Seasonal cycles \\
\hline 1 & $0.56^{*}$ & 0.54 \\
2 & -0.23 & $0.58^{*}$ \\
3 & -0.43 & $0.58^{*}$ \\
4 & 0.30 & 0.36 \\
5 & 0.16 & 0.52 \\
6 & 0.03 & $0.78^{*}$ \\
7 & 0.02 & $0.92^{*}$ \\
8 & $0.51^{*}$ & $0.86^{*}$ \\
9 & 0.43 & $0.89^{*}$ \\
10 & 0.41 & 0.42 \\
11 & $0.69^{*}$ & 0.33 \\
12 & 0.22 & 0.45 \\
13 & 0.34 & $0.67^{*}$ \\
14 & 0.37 & $0.60^{*}$ \\
15 & 0.22 & 0.37 \\
\hline
\end{tabular}

PCI and (i) the NAO and (ii) the Sea Surface Temperature. As the environmental changes induced by the NAO do not occur instantaneously, we took into account the possibility of a lagged response from the phytoplankton and conducted the correlations between PCI and NAO with a lag of zero to 3 months. However, as the response of phytoplankton to the resulting effects of SST fluctuations is quick, the correlation between SST and PCI was not performed at different lags.

To detect changes of intensity and duration in the value of PCI, the cumulative sums method (Ibañez et al., 1993) was used. It consists of subtracting a reference value (here the mean seasonal cycle of the PCI values at each station) from the data, resulting anomalies (Fig. 4c) are then successively added, forming a cumulative function. This analysis was performed on the time series of monthly anomalies of PCI at each station along the route. The cumulative sum method was also used on the altimeter and SST anomaly data. This method is useful for data where high frequency variance may obscure longer-term trends. The relationship between PCI and SeaWiFS was also tested through Spearman rank correlation analysis performed at each station between (i) original data (based on 4 years time series) and (ii) mean seasonal cycles (determined from the 15 stations along the CPR route). The structure (i.e. mean, amplitude and phase) of PCI and SeaWiFS seasonal cycles (12 months time series) was compared.

\section{Results}

3.1 Comparison of temporal structures of two phytoplankton estimator

Seasonal cycles of SeaWiFS and PCI (Fig. 2) identified distinct regimes for the Georges Bank (stations 2 and 3), Shelf Break and Sable Island (stations 6, 7, 8 and 9) and St Pierre Bank (stations 13 and 14). A decrease $(\tau=-0.13, \mathrm{p}<0.5)$ in SeaWiFS Chl $a$ is observed along the E-route towards Newfoundland. Along the CPR route, monthly time-series of PCI and SeaWiFS chlorophyll $a$ showed significant correlation in only $20 \%$ of the stations, with a maximum positive correlation of. 0.69 (Table 1). In contrast, significant relationships between seasonal cycles of PCI and SeaWiFS Chl $a$ were observed in $53 \%$ of the stations along the CPR route (Table 1, Fig. 2), with a maximum positive correlation of 0.92 (Table 1). There is, finally, a significant correlation $\left(\rho_{s}=0.65\right.$, $\mathrm{p}<0.05$ ) between the averaged seasonal cycles of these two estimators of phytoplankton (Fig. 3).

\subsection{Phytoplankton Colour Index and climate indices}

The bloom usually observed between February and May (Riley, 1941) was not existing on Georges Bank (and also stations 13, 14 and 15) in 1997, but an unusual autumn bloom was observed in 1996 (Fig. 4a). In the other stations along the E-route, the usual bloom was observed but during an extended period of time (November 1996-June 1997). Those changes were also visible on the PCI cumulative sums diagram (Fig. 4d). The PCI anomalies cumulative sums analysis revealed different local trends in the time series, with a change of slope in winter 1996/1997 for stations 1 to 5. For stations 6 to 10, the cumulative sums of PCI increased from December 1996 until March 1997 and decreased afterwards. Changes were also observed in SST, with negative anomalies observed between June 1996 and June 1997 in stations 1-9 on the SST Hovmöller diagram (Fig. 5c). Conversely, no specific trends were observed in SST for stations 10 to 15. The SST anomalies cumulative sums analysis (Fig. 5d) revealed different trends depending on the location along the continental shelf. In stations 1 to 5 , the cumulative sums of SST (Fig. 5d) increased until December 1995 and decreased.

No significant trends were observed in PCI time series along the CPR route. Mostly significant inverse relationships occur along the route between the PCI data and SST (Table 2). This is consistent with the shift occurring between their seasonal cycles, with a minimum SST in March occurring near the maximum of PCI (i.e. Spring Bloom period). However, no significant relationships were found between PCI residuals and SST residuals. Although, no correlation was found between simultaneous PCI and NAO time series, positive significant correlations were observed between monthly PCI and NAO with a lag of 2 months (Table 2). 

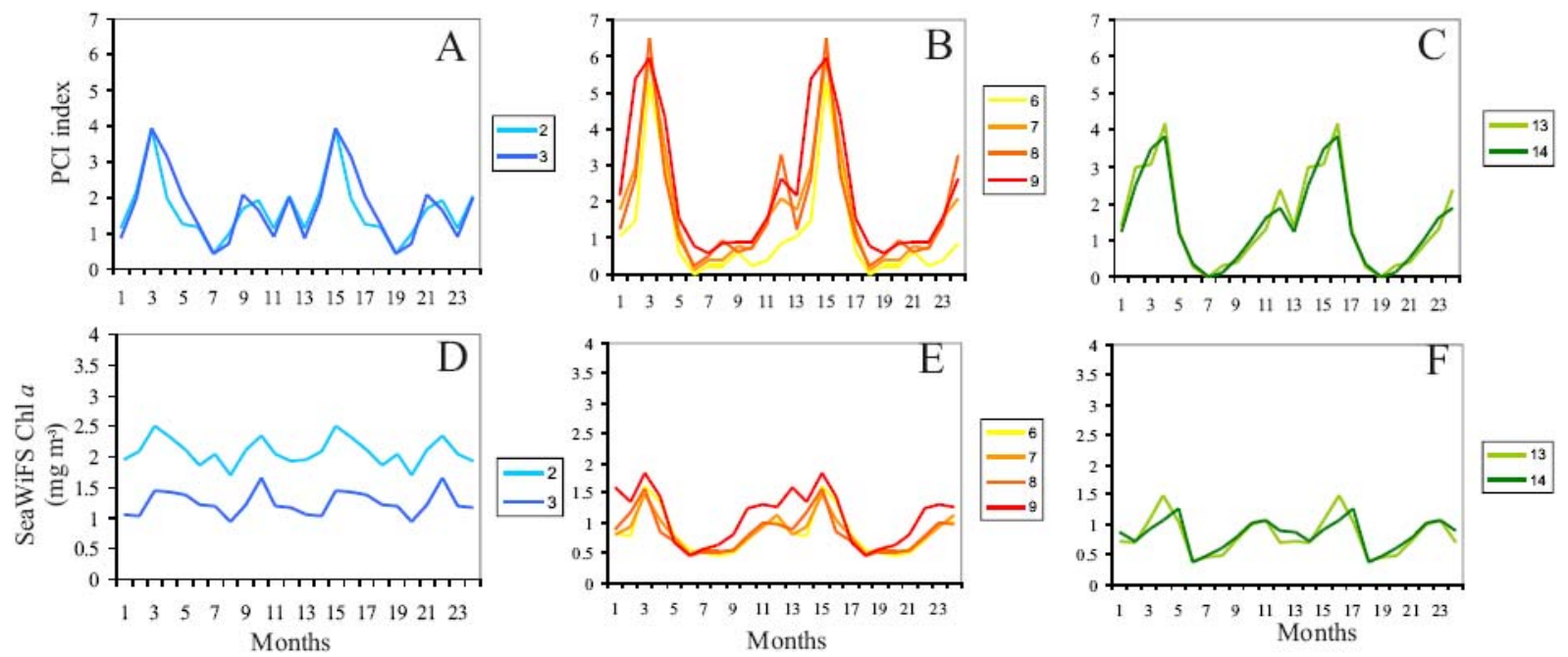

Fig. 2. Seasonal cycles of Phytoplankton Colour Index $(\mathbf{A}, \mathbf{B}, \mathbf{C})$ and SeaWiFS chlorophyll $a\left(\mathrm{mg}^{-3} \mathrm{~m}^{-3} \mathrm{Chl} a ; \mathbf{D}, \mathbf{E}, \mathbf{F}\right)$ along the CPR route (15 stations). The cycles that were significantly correlated were observed on Georges Bank (stations 2 and 3), Shelf Break (Stations 6 and 7), Sable Island (stations 8 and 9) and St Pierre Bank (stations 13 and 14); see Table 2. The cycles have been repeated for 2 years.

Table 2. Results of Spearman correlation analysis between the monthly time series of PCI and NAO and both original and residual (seasonal cycle removed) time series of PCI and SST over the period 1995-1998. *5\% significance level.

\begin{tabular}{|c|c|c|c|c|c|c|}
\hline \multirow[t]{2}{*}{ Stations } & \multicolumn{4}{|c|}{ monthly PCI-NAO } & \multirow{2}{*}{$\begin{array}{c}\text { original data } \\
\text { PCI-SST }\end{array}$} & \multirow{2}{*}{$\begin{array}{c}\text { residual } \\
\text { PCI-SST }\end{array}$} \\
\hline & no lag & 1 month lag & 2 months lag & 3 months lag & & \\
\hline 1 & 0.20 & $0.29 *$ & 0.17 & -0.09 & $-0.38^{*}$ & 0.11 \\
\hline 2 & 0.07 & 0.27 & $0.34 *$ & 0.12 & -0.25 & 0.08 \\
\hline 3 & -0.18 & 0.12 & 0.23 & 0.14 & -0.24 & 0.07 \\
\hline 4 & 0.08 & 0.24 & 0.20 & -0.02 & -0.21 & 0.15 \\
\hline 5 & 0.01 & 0.03 & 0.15 & 0.06 & $-0.39 *$ & 0.08 \\
\hline 6 & 0.00 & 0.25 & $0.39 *$ & -0.02 & $-0.50^{*}$ & 0.03 \\
\hline 7 & 0.08 & 0.25 & $0.34 *$ & 0.10 & $-0.56^{*}$ & 0.02 \\
\hline 8 & 0.10 & $0.35 *$ & 0.22 & -0.04 & $-0.48 *$ & 0.06 \\
\hline 9 & 0.07 & 0.10 & 0.17 & 0.13 & $-0.59 *$ & -0.02 \\
\hline 10 & -0.14 & 0.23 & $0.36^{*}$ & 0.18 & $-0.71 *$ & -0.17 \\
\hline 11 & -0.10 & 0.23 & $0.45^{*}$ & 0.11 & $-0.69^{*}$ & -0.13 \\
\hline 12 & 0.04 & 0.23 & $0.36^{*}$ & 0.19 & $-0.70^{*}$ & 0.11 \\
\hline 13 & -0.05 & 0.22 & $0.35^{*}$ & 0.13 & $-0.63^{*}$ & 0.05 \\
\hline 14 & -0.02 & 0.22 & 0.24 & 0.19 & $-0.59 *$ & 0.01 \\
\hline 15 & -0.07 & 0.28 & 0.20 & 0.13 & $-0.67 *$ & 0.02 \\
\hline
\end{tabular}

\subsection{Phytoplankton and mesoscale physical processes}

The annual component of altimeter Sea Level Anomaly (SLA) and tidal aliasing (Fig. 6b) revealed the alternation between positive and negative SLA with annual periodicity. This corresponds to the rise and fall of the sea surface resulting from the expansion and contraction of the ocean due to seasonal heating and cooling. There was a lag of two months in the maximum rise and fall of the water level between stations 1 and 15. The amplitude of the annual component is reduced northward along the route where the surface water is cooler (see Fig. 5). Positive and negative anomalies have been identified in the SLA residuals on Hovmöller diagram (e.g. marked $+/-$, Fig. 6c). Those anomalies can influence the spatial structure of PCI. In particular, PCI anomaly structures corresponding to the SLA residual structures were identified. Lower/higher SLA residuals (identified respectively by signs - and + in Fig. 6c) are associated with higher/lower Chl $a$ values (identified respectively by signs + and - in Fig. 4c). However, there was no statistical significant correlation between residuals of PCI and SLA for the whole region. 
Table 3. Structure of the seasonal cycles of Phytoplankton Colour Index (PCI) and SeaWiFS chlorophyll $a$ over the period $1997-1998$.

\begin{tabular}{|c|c|c|c|c|c|c|}
\hline \multirow[b]{2}{*}{ PCI } & \multicolumn{2}{|c|}{$\begin{array}{c}\text { Annual } \\
\text { Amplitude Phase }\left(^{\circ}\right)\end{array}$} & \multicolumn{2}{|c|}{$\begin{array}{c}\text { Semi-annual } \\
\text { Amplitude Phase }\left(^{\circ}\right)\end{array}$} & \multirow{2}{*}{$\begin{array}{c}\text { Mean } \\
1.57\end{array}$} & \multirow{2}{*}{$\begin{array}{c}\text { Ratio of the amplitudes } \\
\text { (Semi-annual/Annual) } \\
0.70\end{array}$} \\
\hline & 1.57 & 74 & 1.10 & 170 & & \\
\hline SeaWiFS (mg m $\left.{ }^{-3} \mathrm{Chl} a\right)$ & 0.20 & 28 & 0.23 & 215 & 0.94 & 1.15 \\
\hline
\end{tabular}

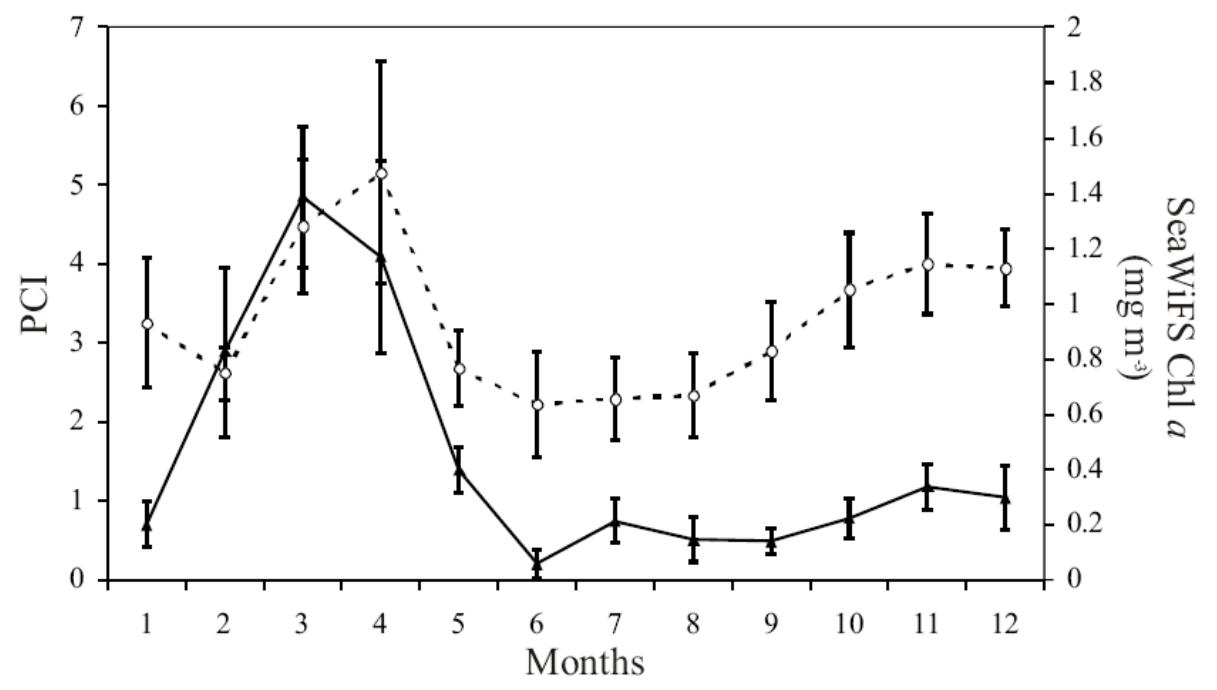

Fig. 3. Mean seasonal cycles of PCI (black triangles) and SeaWiFS chlorophyll $a$ (mg.m ${ }^{-3}$ Chl $a$; open dots) over the period $1997-1998$ along the CPR route. The error bars are the standard deviation.

Changes in geostrophic surface flow can be derived from altimeter data. This was done by measuring the difference in SLA residuals between 2 locations specifically chosen as representative of the shelf area $\left(\mathrm{A} ; 44^{\circ} \mathrm{N} 62^{\circ} \mathrm{W}\right)$ and the open ocean (B; $42^{\circ} \mathrm{N} 60^{\circ} \mathrm{W}$; Fig. 1$)$, removing the annual component and tidal aliasing for a 9 years period 1992-2001 and applying the geostrophic relation for surface current:

$$
f v=-g \frac{\Delta E}{\Delta x}
$$

Where $f$ is the coriolis parameter, $v$ is the surface velocity, $g$ the acceleration due to gravity, $\Delta x$ is the distance between $\mathrm{A}$ and $\mathrm{B}$ and $\Delta E$ is the difference in SLA. Between October 1992 and July 1995, the relative mean geostrophic flow moving northeast between the two stations was $\sim 1 \mathrm{~km}^{\text {.day }}{ }^{-1}$. Then, after May 1996, the relative mean flow reversed (moving southwest) with a mean speed of $\sim 3 \mathrm{~km}^{\text {day }}{ }^{-1}$ until April 1998. The correlation coefficient of the slope difference or geostrophic flow with NAO over the 9 year period was 0.44 for zero lag. A maximum correlation of 0.72 found with a NAO lag of 9 months. The cumulative sums of geostrophic current (from SLA data effectively giving a mean distance of travel between the 2 stations $\mathrm{A}$ and $\mathrm{B}$ ) was positively correlated with cumulative NAO monthly index (Fig. 7, $\rho_{s}=0.60, \mathrm{p}<0.0001$ ).

\section{Discussion}

4.1 Seasonal cycles of Phytoplankton Colour Index and SeaWiFS chlorophyll $a$

Along the E-route, a significant relationship has been observed between the seasonal cycles of two estimators of phytoplankton biomass (i.e. PCI and SeaWiFS chlorophyll $a$ ) in $53 \%$ of the stations, with a maximum positive correlation of $\rho_{s}=0.92$. A similar comparison, based on monthly time series of PCI and SeaWiFS over the period 1997-2002, made for the Central NE Atlantic and the North Sea, gave a Pearson's correlation coefficient of 0.79 (Raitsos et al., 2005). However, based on monthly time series, only $20 \%$ of the stations investigated here showed a significant relationship. This strongly suggests that the relationship between PCI and SeaWiFS varies spatially (i.e. the average distance between 2 stations along the E-route is $100 \mathrm{~km}$ ) and that the most of the observed variability is driven by small-scale processes. As Raitsos et al. (2005) took into account CPR sampling stations located all over the Central NE Atlantic and the North Sea, and did not compare individual stations, they smoothed the above-mentioned spatial variability that might have been present. 

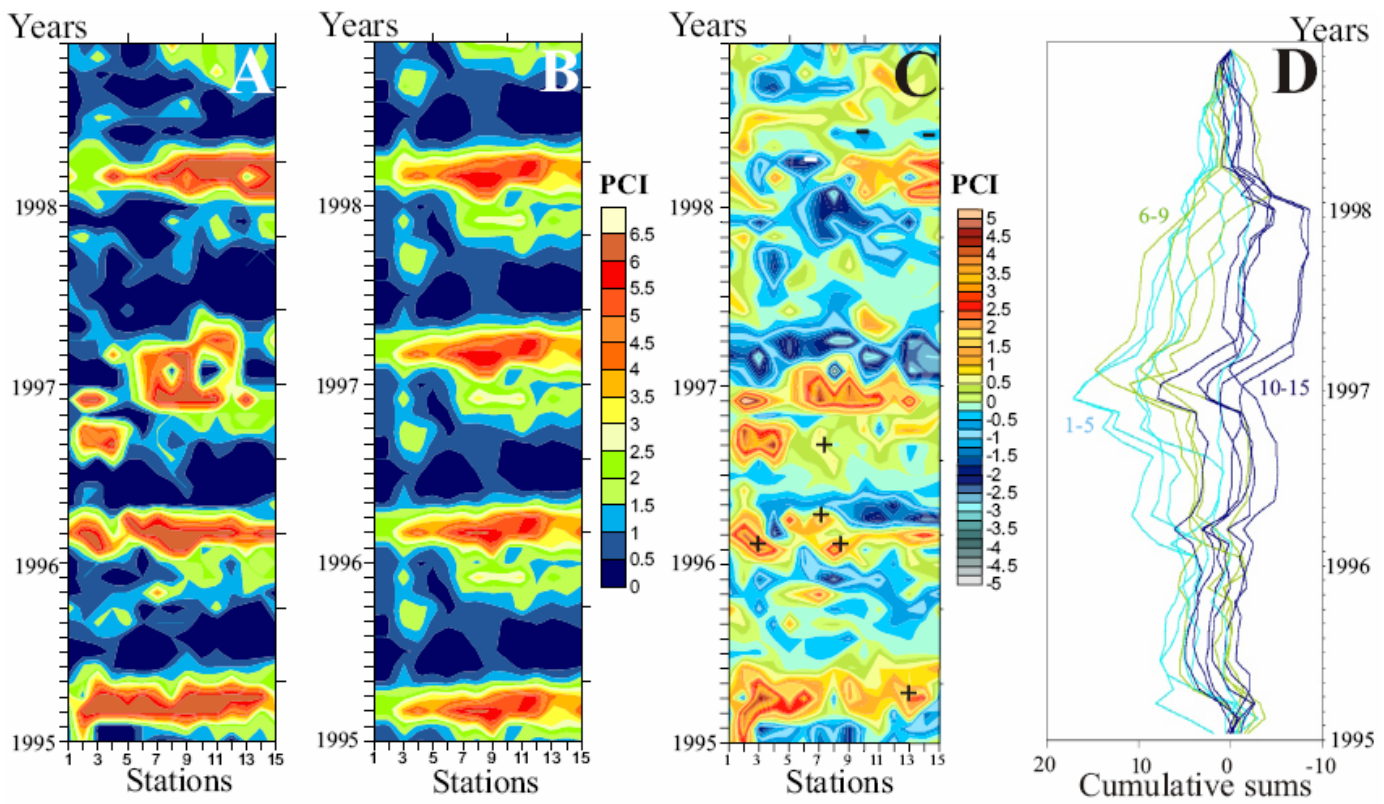

(PCI anomalies, index month)

Fig. 4. Hovmöller diagram of original data (A), seasonal cycle (B) and anomalies after removing the seasonal cycle (C) of Phytoplankton Colour Index (PCI) for the 15 stations sampled on the CPR route between January 1995 and December 1998. Cumulative sum analysis was performed on PCI anomalies for all the stations (D), over the period 1995-1998. Low (high) values of PCI are marked with - $(+)$ sign (these correspond with positive (negative) anomalies marked with $+(-)$ in Fig. 6).
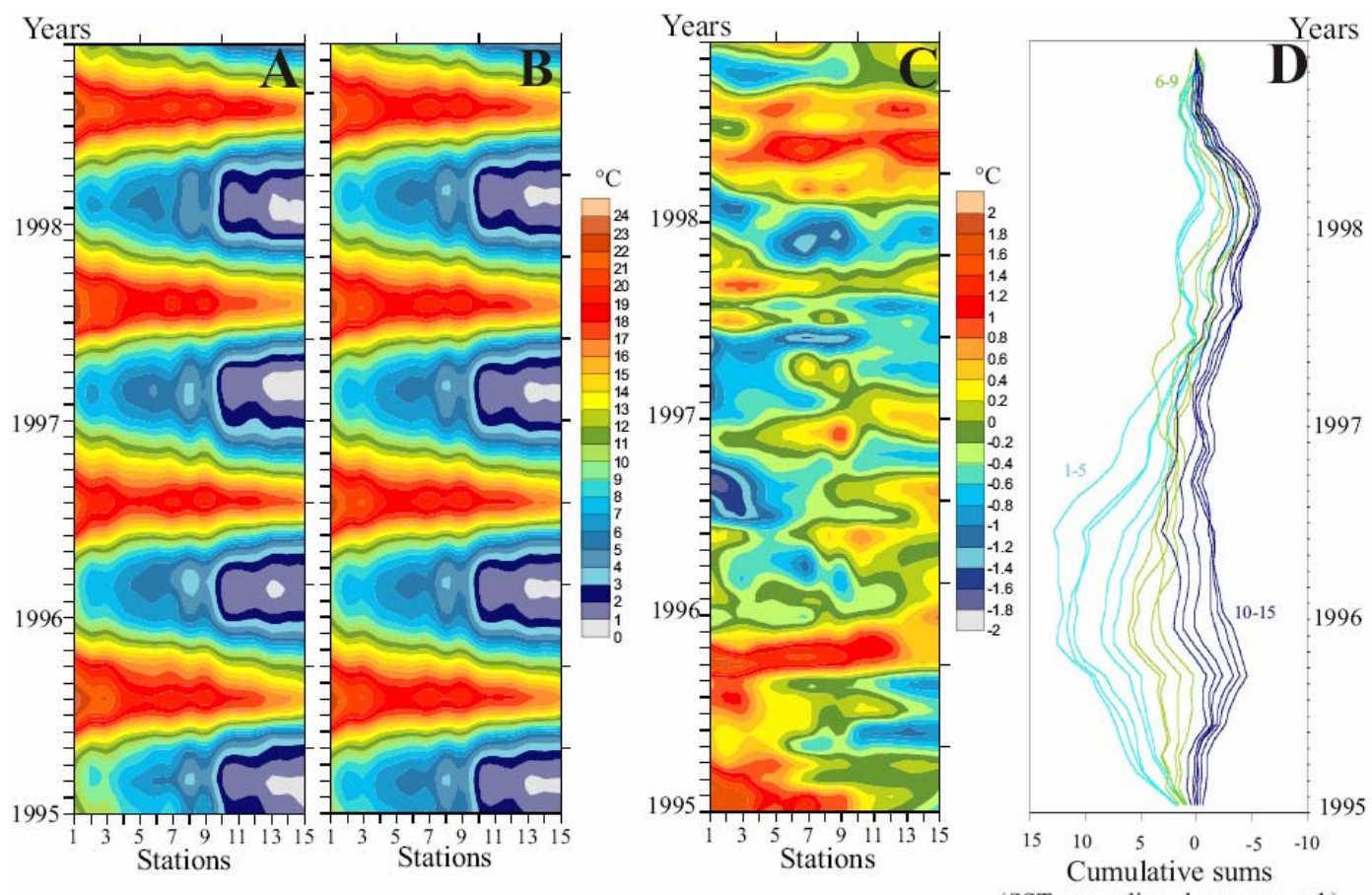

(SST anomalies, degrees month)

Fig. 5. Hovmöller diagram of original data (A), seasonal cycle (B) and anomalies after removing the seasonal cycle (C) of Sea Surface Temperature (SST) for the 15 stations sampled on the CPR route between January 1995 and December 1998. Cumulative sum analysis was performed on SST anomalies for all the stations (D), over the period 1995-1998. 

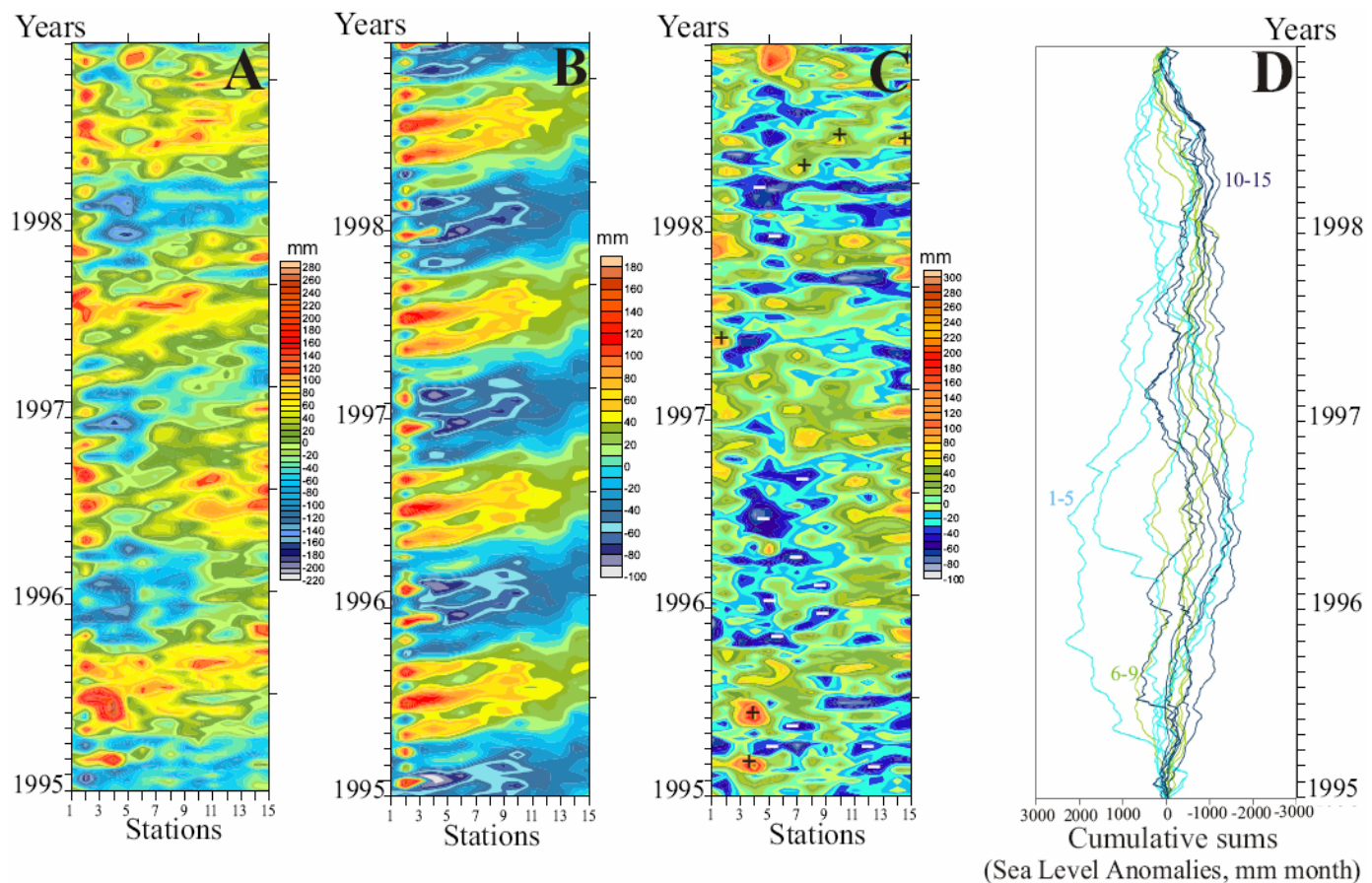

Fig. 6. Hovmöller diagram of original data (A), seasonal cycle (B) and anomalies after removing the seasonal cycle (C) of Sea Surface Heights (SSH) for the 15 stations sampled on the CPR route between January 1995 and December 1998. Cumulative sum analysis was performed on the residuals of Sea Level Anomalies (SLA) for all the stations (D), over the period 1995-1998.

In addition to the moderate level of association between the seasonal cycles of PCI and SeaWiFS (Table 1), the structure of the seasonal cycle also differs (Table 3). A simple seasonal cycle can be considered as a simple three component model, i.e. the sum of the mean, the fundamental component (annual component) and its first distorting harmonic or overtone (semi-annual component). The annual and semiannual components of PCI and SeaWiFS data, derived using Fourier analysis, are listed in Table 3 with their mean value. The combination of phases and amplitudes of the annual and semi-annual components estimated for PCI (Table 3; see also Fig. 3) leads to an increased amplitude of the spring bloom and a weakened autumn bloom. By contrast, the phases for SeaWiFS data tend to split the maximum amplitude region into a spring and autumn blooms (Fig. 3). In addition, the semi-annual SeaWiFS signal is relatively larger than the semi-annual PCI signal (Table 3). The phases of the PCI and SeaWiFS annual cycle differ by ca. $46^{\circ}$ (Table 3 ), indicating a ca. 1.5 months lag between for the PCI maximum value with respect to the overall increased levels of SeaWiFS between autumn and spring. The difference between the ratio of the mean to the annual component (SeaWiFS $\sim 5$, PCI $\sim 1$ ) suggests a clear divergence in the two methods for assessing chlorophyll $a$ levels, especially during the summer minimum where PCI estimates are near zero in June. Further examination of the seasonal cycle observed along the E-route shows a more significant relative contribution of the semi-annual component to both PCI and SeaWiFS signals on Georges Bank (Fig. 2a, d) and St Pierre Bank (Fig. 2c, f) when compared to the near shelf break stations 6-9 (Fig. 2b, e). In addition, the amplitude of the seasonal cycle reached maximum levels near the shelf break stations 6-9 (see Fig. 2). The comparison of PCI and SeaWiFS seasonal cycles thus leads to the conclusion that:

- Overall, the Chl $a$ and PCI seasonal cycles for stations 1 to 15 are similar but the shelf break stations show a relatively reduced semi-annual distortion;

- The mean levels of Chl $a$ and PCI decrease from stations 1 to 15 .

- The mean SeaWiFS levels for the seasonal cycle (Fig. 3) are relatively higher than mean PCI levels showing that the "zero PCI" does not correspond to "zero SeaWiFS $\mathrm{Chl} a$ " phenomena. We note that for PCI values of 0 1, Raitsos et al. (2005) found SeaWiFS Chl $a$ values of $\sim 1-1.65 \mathrm{mg} \mathrm{m}^{-3}$ whereas in this study this range of values corresponded to SeaWiFS Chl $a$ values of $\sim 0.8 \mathrm{mg} \mathrm{m}^{-3}$. In this study, the maximum PCI value of the seasonal cycle of $\sim 5$ corresponds to a SeaWiFS Chl $a$ of $\sim 1.5 \mathrm{mg} \mathrm{m}^{-3}$ (about three times less than estimated from Raitsos et al., 2005). This implies that different regions would require different calibrations of the relationship between PCI and SeaWiFS Chl $a$. 


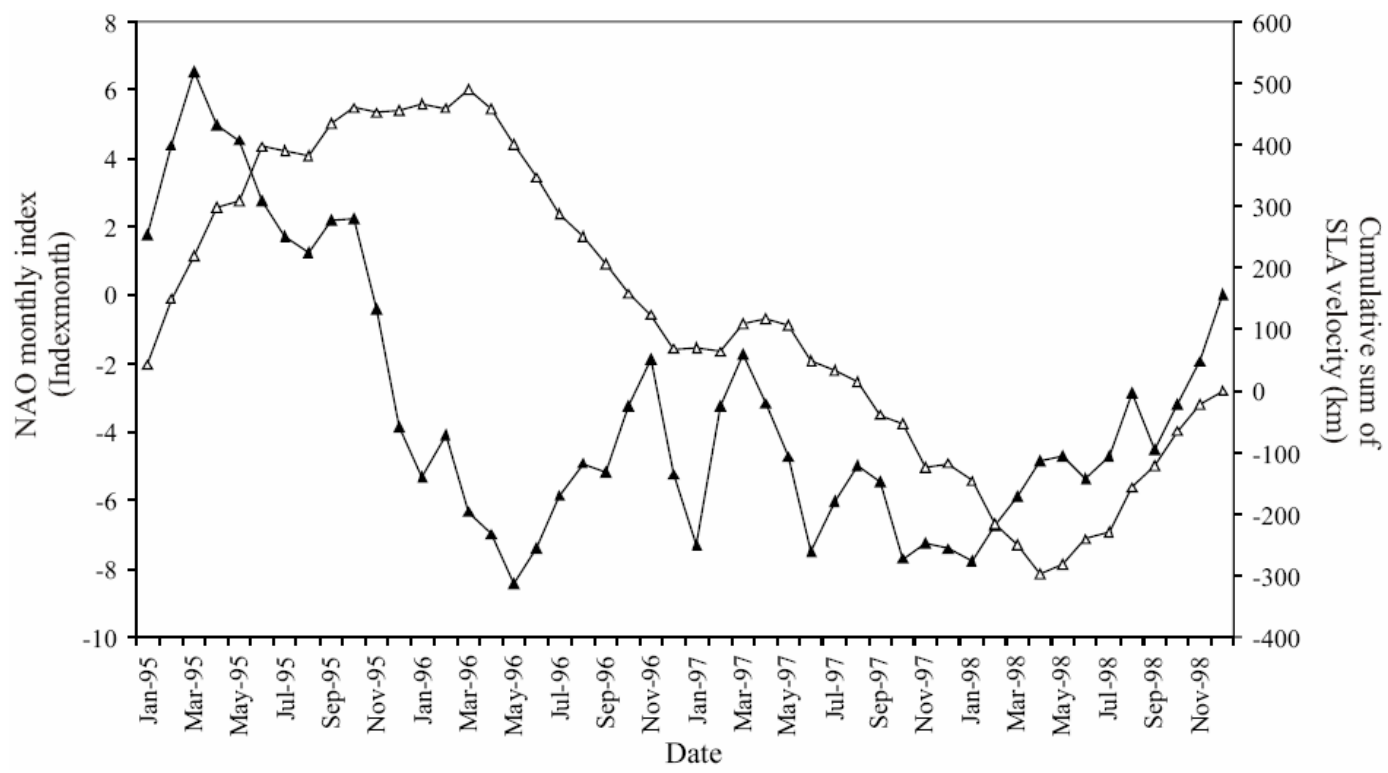

Fig. 7. Cumulative NAO (index month; black triangles) and cumulative geostrophic current (white triangles) derived from altimeter sea level anomaly $(\mathrm{km})$ over the period 1995-1998.

\subsection{Influence of the climate}

Along the CPR route, phytoplankton was significantly correlated with monthly NAO (with a lag of 1-2 months). PCI anomalies cumulative sums analysis revealed changes in trends of the time series, with a change in slope between December 1996 and March 1997 for stations 2 to 13. In addition, there was no spring bloom on Georges Bank in 1997 (Fig. 4a). Finally, we observed a decrease in SST between June 1996 and June 1997 on the Scotian Shelf (Fig. 5c). The earlier period (winter 1995-1996) corresponds to the most negative value observed in NAO winter index since 1970s (Hurrell, 1995) with a maximum change between positive and negative values between 1995 and 1996. After the NAO index's large drop in 1996, the Labrador Subarctic Slope Water (LSSW, i.e. cool, fresh water poor in nutrients; Petrie and Yeats, 2000) advanced along the shelf break, displacing the Atlantic Temperate Slope Water (ATSW, i.e. relatively warm and salty) offshore and penetrating to the southwest as far as the Middle Atlantic Bight (Mercina, 2001). Between October 1992 and July 1995, the geostrophic flow relative to the long term mean estimated from altimeter data was moving northeast (i.e. corresponding to ATSW flowing along the continental shelf). This flow towards Newfoundland was $\sim 1 \mathrm{~km}$ day $^{-1}$ until July 1995 , it then reversed to $\sim 3 \mathrm{~km} \mathrm{day}^{-1}$ from May 1996 until April 1998. It is then suggested that the ATSW was progressively replaced along the shelf and slope region by LSSW from 1997 to February 1998 , in accordance with previous observations (Greene et al., 2003). These water masses movement are also associated with a decrease in surface salinity on Georges Bank be- tween 1995 and 1997 (Smith et al., 2001). The movement of water masses along the Scotian Shelf is then strongly influenced by the different phases of NAO. The changes in flow along the Scotian Shelf can be understood by considering the climate change from NAO positive conditions (ending in winter 1994-1995) to NAO negative conditions (starting in summer 1995). The weakened wind stress (or reduced curl magnitude) over the North Atlantic associated with negative NAO conditions results in a reduced anticyclonic circulation or in a cyclonic anomaly. The sea level anomaly picture for December 1997 (Fig. 8) shows the cyclonic anomaly with a central regional low value of $\sim-3 \mathrm{~cm}$ and inverse anomaly of $\sim+4 \mathrm{~cm}$ in exterior regions. This illustrates a weakening of the North Atlantic circulation resulting from NAO negative conditions.

In physics, the deformation of a surface or circular membrane is defined in terms of Chladni's figures or normal modes. Oceanographers sometimes prefer a description of the sea surface elevation deformation in terms of poles (c.f. electrostatics) and the interpretation can be straightforward using the geostrophic relation. We have analyzed the response of the North Atlantic Ocean to westerly wind stress or NAO for (i) a mean trend (climate change), (ii) along $35^{\circ} \mathrm{W}$, (iii) an 8 year period response and (iv) an abrupt change in NAO (Pingree, 2002, 2005). The basic structure or response to a change in NAO is a quadrupole though the detail and scale may differ. With a sudden decrease in winter NAO sea surface elevation falls along the Gulf Stream and the North Atlantic Current and rises to the north in the Labrador, Irminger and Iceland Basins and to the south in the Canary Basin and towards America (see Fig. 8). 


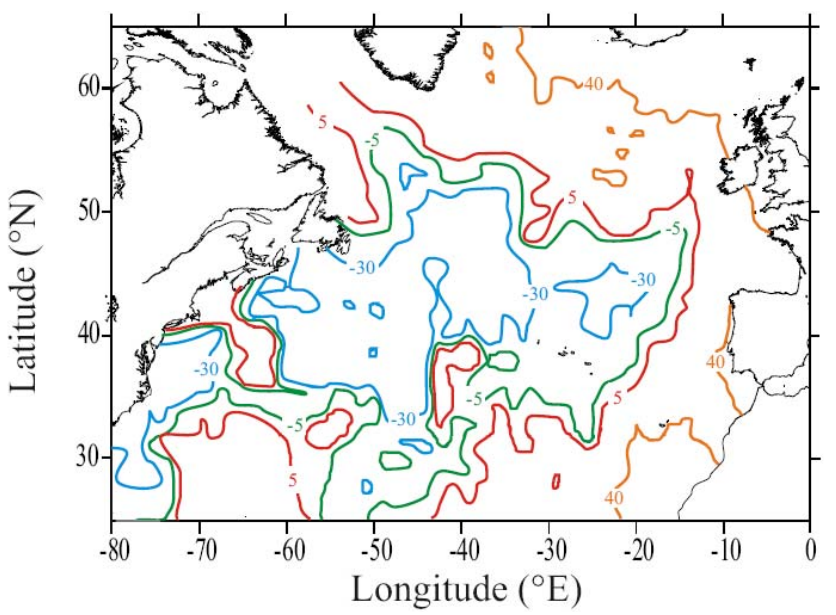

Fig. 8. Sea Level Anomaly (SLA, in mm) for the winter of 1997/98 $(\sim$ centered on 15 December 1997$)$ showing cyclonic tendency for the North Atlantic under negative phase of the North Atlantic Oscillation (NAO).

Further distortion due to asymmetry of circulation (e.g. western intensification, Stommel, 1958) within the North Atlantic Ocean Basin is such that the raised elevation regions can join along the eastern margin of the North Atlantic Ocean. This also happened 2 years earlier in December 1995 following the sudden fall of NAO in 1995 (see Pingree 2006). The fall in sea elevation is intensified in the Gulf Stream and North Atlantic Current region (making the quadrupole) with depressions of sea elevation of $\sim-10 \mathrm{~cm}$ near $38^{\circ} \mathrm{N}, 55^{\circ} \mathrm{W}$ and $\sim-14 \mathrm{~cm}$ near $39^{\circ} \mathrm{N}, 45^{\circ} \mathrm{W}$ and $\sim-12 \mathrm{~cm}$ near $44^{\circ} \mathrm{N}$, $37^{\circ} \mathrm{W}$ in December 1997 (see Fig. 8).

There is strong evidence that production rates of the copepod Calanus finmarchicus were limited by the lack of food on the southern flank of Georges Bank during April 1997 (Campbell et al., 2001). This observation is consistent with the absence of a phytoplankton spring bloom in 1997 on the Georges Bank (Fig. 4a). The timing and development of density stratification on Southern Georges Bank have, however, also been shown to influence the growth and recruitment of copepods (Bisagni, 2000). The changes in seawater characteristics (i.e. temperature, salinity, nutrient levels) following the inflow of LSSW might have modified the timing and development of the spring bloom and the density stratification on Georges Bank, resulting in the absence of a spring bloom in 1997. Greene and Pershing (2003) showed a lag of 2 years between the negative NAO event of winter 1995-1996 and the Calanus finmarchicus decline in the Gulf of Maine. It is finally suggested that such modifications in the ecosystem might have a strong impact on the higher levels of the food web. This is especially critical in a region like Georges bank that is a large retention area for Atlantic herring, cod, haddock, hake and flounder (Backus, 1987).

\subsection{Influence of mesoscale physical processes}

The annual component of Sea Level Anomalies (SLA) has shown two structures along the CPR route:

- a lag of two months in the rise and fall of the water level between station 1 and 15 (Fig. 6b);

- a decrease in the amplitude of the annual component northward along the route (Fig. 6b), where the surface water is cooler.

The expansion and contraction of the water column, represented by the annual component, is associated with the seasonal changes in SST. Moving northward along the E-route, the mean temperature of the seawater is cooler (Fig. 5a), and the heat necessary to expand the water column correspondingly is greater. Part of this lag corresponds to a delayed heating cycle further north. The spring bloom is delayed by about a month due to the delayed onset of stratification (i.e. maximum of the spring bloom in March for stations 1-8 and in April for stations 9-15; see Fig. 4b).

More specifically, positive and negative anomalies have been identified in SLA on the Hovmöller diagram (Fig. 6c). Specific structures have also been identified in PCI. Negative anomalies visually correspond to areas of high chlorophyll $a$ concentration and positive anomalies are usually associated with low SeaWiFS chlorophyll $a$ concentrations. Negative SLA anomalies, corresponding to cyclonic eddies, are associated with high levels of inorganic nutrients reintroduced in the water column by localised upwellings (Hitchcock et al., 1993; Arístegui et al., 1997). In contrast, positive anomalies corresponding to anticyclonic eddies are associated with depressed isotherms and low levels of inorganic nutrients. These processes are thus likely to modify the development of localised phytoplankton blooms and then influence the concentration in SeaWiFS chlorophyll $a$ observed at the same location. However, there was no significant overall correlation between residuals of PCI and SLA. Mouriño et al. (2005) have shown that mesoscale features are not always associated with changes in biology. On the Shelf, SLA anomalies may not be related to eddies, and result from different causes (e.g. wind set-up, circulation, tidal aliasing, surges) that may not correlate directly with $\mathrm{Chl} a$. Moreover, $\mathrm{Chl} a$ anomalies are likely to have a maximum signal in the productive season due to variations in the timing of the spring bloom whereas SLA anomalies are not seasonally constrained. These observations lead to the conclusion that except in the open ocean, it is difficult to state unambiguously that there is a relation between altimeter anomalies and phytoplankton structures.

Gulf Stream rings have been identified as moving towards the Scotian shelf between September 1997 and December 2000 (Leterme and Pingree, 2007), but none of them (based on the position of the centre of the eddy) was actually observed crossing the shelf break. As a consequence, the positive and negative shelf anomalies identified in SLA between 
1995 and 1998 do not seem to be related to Gulf Stream rings. However, a positive SLA anomaly observed on the southern flank of the Georges Bank (i.e. our stations 2 and 3) in May-June 1997 has been identified by Ryan et al. (2001) as a warm-core ring (anticyclone). Low SeaWiFS Chl $a$ features related to anticyclonic eddies were observed near Georges Bank in February and March 1999, but these could only influence stations 1 and 4 of the E-route. Two such anticyclonic eddies were observed at Station 4 in 1995 near Georges Bank. These observations corroborate the possible observation of anticyclonic rings on the southern flank of the Georges Bank. A more extended analysis of sea level anomalies showed that a few of these relatively smaller anticyclonic eddies could move cyclonically around a larger cold core negative anomaly or Gulf Stream Ring in the ocean region and reach the continental slope region near Station 6 ( $>200 \mathrm{~m}$ depth). From here they tended to move southward along the slope region around Georges Bank and travel as far as Cape Hatteras at speeds of $4 \mathrm{~km} \mathrm{day}^{-1}$ with a wavelength of $\sim 300 \mathrm{~km}$ between successive positive anomalies. Corresponding SeaWiFS structure showed that the centre of the anticyclonic structure was low in chlorophyll $a$ and two such anticyclonic features influencing the Georges Bank region in August 2001 have been described (e.g. marked B on Fig. 13 of Leterme and Pingree, 2007). The shelf Chl $a$ was entrained into the ocean by the ocean eddies from outer regions (see Figs. 3 and 13 of Leterme and Pingree, 2007). The interactions of anticyclonic rings with shelf water masses, via the eddy swirl currents may then modify the distribution of phytoplankton and zooplankton species, as well as the retention of fish larvae on the southern flank of the Georges Bank with critical implications for fisheries (Ryan et al., 2001; Campbell et al., 2001).

Acknowledgements. We thank the SeaWiFS Project Office for providing high resolution of SeaWiFS data. Altimeter data were received from AVISO and CLS. Part of this research was funded by a DEFRA contract (CSA 6193/AE1147): "Environmental change and biodiversity". A funding consortium comprising governmental agencies from Canada, France, the Netherlands, Portugal, and the USA supports the CPR survey. The survey depends on the voluntary cooperation of owners, masters, and crews of merchant vessels that tow CPR on regular routes. We are grateful to L. Seuront for helpful discussions and to C. Greene for his comments on the manuscript. We wish to thank the CPR survey team past and present.

Edited by: E. J. M. Delhez

\section{References}

Arístegui, J., Tett, P., Hernández-Guerra, A., Basterretxea, G., Montero, M. F., Wild, K., Sangra, P., Hernandez-Leon, S., Canton, M., Garcia-Braun, J. A., Pacheco, M., and Barton, E. D.: The influence of island-generated eddies on chlorophyll distribution: a study of mesoscale variation around Gran Canaria, Deep-Sea Res., 44, 71-96, 1997.

Backus, R. H.: Georges Bank, MIT Press, Cambridge, Massachusetts, 1987.

Bisagni, J. J.: Estimates of vertical heat flux and stratification from Southern Georges Bank, interannual variability, 19851995, Cont. Shelf Res., 20, 211-234, 2000.

Bisagni, J. J., Seemann, K. W., and Mavor, T. P.: High-resolution satellite-derived sea-surface temperature variability over the Gulf of Maine and Georges Bank region, 1993-1996, Deep-Sea Res. II, 48, 71-94, 2001.

Campbell, R. G., Runge, J. A., and Durbin, E. G.: Evidence for food limitation of Calanus finmarchicus production rates on the southern flank of Georges Bank during April 1997, Deep-Sea Res. II, 48, 531-549, 2001.

Colebrook, J. M. and Robinson, G. A.: Continuous Plankton Records: seasonal cycles of phytoplankton and copepods in the northeastern Atlantic and the North Sea, Bull. Mar. Ecol., 6, 123139, 1965.

Garcia-Moliner, G. and Yoder, J. A.: Variability in pigment concentration in warm core rings as determined by coastal zone color scanner satellite imagery from the Mid-Atlantic Bight, J. Geophys. Res., 99(C7), 14 277-14290, 1994.

Gonzalez, N., Anadon, R., Mourino, B., Fernandez, E., Sinha, B., Escanez, J., and de Armas, D.: The metabolic balance of the planktonic community in the North Atlantic Subtropical Gyre: The role of mesoscale instabilities, Limnol. Oceanogr., 46, 946952, 2001.

Greene, C. H. and Pershing, A. J.: The response of Calanus finmarchicus populations to climate variability in the Northwest Atlantic: basin-scale forcing associated with the North Atlantic Oscillation, ICES J. Mar. Sci., 57, 1536-1544, 2000.

Greene, C. H. and Pershing, A. J.: The flip-side of the North Atlantic Oscillation and modal shifts in slope-water circulation patterns, Limnol. Oceanogr., 48(1), 319-322, 2003.

Greene, C. H., Pershing, A. J., Conversi, A., Planque, B., Hannah, C. G., Sameoto, D., Head, E., Smith, P. C., Reid, P. C., Jossi, J. W., Mountain, D. G., Benfield, M. C., Wiebe, P. H., and Durbin, E. G.: Trans-Atlantic responses of Calanus finmarchicus populations to basin-scale forcing associated with the North Atlantic Oscillation, Progr. Oceanogr., 58, 301-312, 2003.

Griffiths, D. K., Pingree, R. D., and Sinclair, M.: Summer tidal fronts in the near arctic regions of Foxe Basin and Hudson Bay, Deep-Sea Res., 28, 865-873, 1981.

Hays, G. C. and Warner, A. J.: Consistency of towing speed and sampling depth for the continuous plankton recorder, J. Mar. Biol. Assoc. of the U.K., 73, 967-970, 1993.

Hitchcock, G. L., Mariano, A. J., and Rossby, T.: Mesoscale pigments fields in the Gulf Stream: observations in a meander crest and trough, J. Geophys. Res., 98, 8425-8445, 1993.

Hurrell, J. W.: Decadal trends in the North Atlantic Oscillation: Regional temperatures and precipitation, Science, 269, 676-679, 1995.

Ibañez, F., Fromentin, J. M., and Castel, J.: Application de la méthode des sommes cumulées à l'analyse des séries chronologiques océanographiques, Compte Rendus de l'Académie des Sciences de Paris, Sciences de la vie/Life sciences, 316, 745-748, 1993.

Kendall, M. and Stuart, A.: The advanced theory of statistics, 
Hafner, 1966.

Kennelly, M. A., Evans, R. H., and Joyce, T. M.: Small scale cyclones on the periphery of a Gulf Stream warm core ring, J. Geophys. Res., 95(C5), 8845-8857, 1985.

Legendre, L. and Demers, S.: Towards Dynamic Biological Oceanography and Limnology, Can. J. Fish. Aquat. Sci., 41, 219, 1984.

Legendre, L., Demers, S., and Lefaivre, D.: Biological production at marine ergoclines, in: Marine Interface Ecohydrodynamics, edited by: Nihoul, J. C. J., 1-29, Elsevier, Amsterdam, 1986.

Leterme, S. C. and Pingree, R. D.: The Gulf Stream, Rings and North Atlantic Eddy structure from remote sensing (Altimeter and SeaWiFS), J. Mar. Syst., in press, 2007.

Le Traon, P. Y., Nadal, F., and Ducet, N.: An improved mapping method of multisatellite altimeter data, J. Atm. Oceanic Technol., 15, 522-534, 1998.

Lindley, J. A. and Williams, R.: Plankton of the Fladen Ground during FLEX 76. II. Population dynamics and production of Thysanoessa inermis (Crustacea: Euphausiacea), Mar. Biol., 57, 7986, 1980.

Longhurst, A.: Ecological geography of the sea, Academic Press Ltd, London, 1998.

Mackas, D. L., Denman, K. L., and Abbot, M. R.: Plankton patchiness: biology in the physical vernacular, Bull. Mar. Sci., 37, 652-674, 1985.

Margalef, R.: What is an upwelling ecosystem?, in: Upwelling Ecosystems, edited by: Boje, R. and Tomczak, M., 12-14, Springer-Verlag, Berlin, 1978.

MERCINA: Gulf of Maine/Western Scotian Shelf ecosystems respond to changes in ocean circulation associated with the North Atlantic Oscillation, Oceanography, 14, 76-82, 2001.

Mouriño, B., Fernández, E., Pingree, R. D., Sinha, B., Escánez, J., and de Armas, D.: Constraining effect of mesoscale features on carbon budget of photic layer in the NE subtropical Atlantic, Mar. Ecol. Progr. Ser., 287, 45-52, 2005.

Mueller, J. L. and Austin, R. W.: Ocean Optics Protocols for SeaWiFS Validation, in: NASA Technical Memorandum 104566, Revision 1, SeaWiFS Technical Report Series, Vol. 25, edited by: Hooker, S. B., Firestone, E. R., and Acker, J. G., Greenbelt, Maryland, 1995.

Petrie, B. and Yeats, P.: Annual and interannual variability of nutrients and their estimated fluxes in the Scotian Shelf-Gulf of Maine region, Can. J. Fish. Aqu. Sci., 57, 2536-2546, 2000.

Pingree, R. D.: A component of Labrador sea water in the Bay of Biscay, Limn. Oceanogr., 18(5), 711-718, 1973.
Pingree, R. D., Holligan, P. M., and Mardell, G. T.: Phytoplankton growth and cyclonic eddies, Nature, 278, 245-247, 1979.

Pingree, R. D., Garcia-Soto, C., and Sinha, B.: Position and structure of the Subtropical/Azores Front region from combined Lagrangian and remote sensing IR/altimeter/SeaWiFS measurements, J. Mar. Biol. Assoc. U.K., 795, 769-792, 1999.

Pingree, R. D.: Ocean structure and climate (Eastern North Atlantic): in situ measurement and remote sensing altimeter, J. Mar. Biol. Assoc. U.K., 82, 681-707, 2002.

Pingree, R. D.: North Atlantic and North Sea Climate Change: curl up, shut down, NAO and Ocean colour, J. Mar. Biol. Assoc. U.K., $85,1301-1315,2005$.

Pingree, R. D.: Interactive comment on "Temporal and spatial characteristics of sea surface height variability in the North Atlantic Ocean” by D. Cromwell, Ocean Sci. Discuss., 3, S308-S312, 2006.

Raitsos, D. E., Reid, P. C., Lavender, S. J., Edwards, M., and Richardson, A. J.: Extending the SeaWiFS chlorophyll data set back 50 years in the northeast Atlantic, Geophys. Res. Lett., 32, L06603, doi:10.1029/2005GL022484, 2005.

Riley, G. A.: Plankton studies, V. Georges Bank, Bulletin of the Bingham Oceanographic Collection, 7, 1-73, 1941.

Ryan, J. P., Yoder, J. A., Barth, J. A., and Cornillon, P. C.: Chlorophyll enhancement and mixing associated with meanders of the shelf break front in the Mid-Atlantic Bight, J. Geophys. Res., 104(C10), 23 479-23 493, 1999.

Ryan, J. P., Yoder, J. A., and Townsend, D. W.: Influence of a Gulf Stream warm-core ring on water mass and chlorophyll distributions along the southern flank of Georges Bank, Deep-Sea Res. II, Top. Stud. Oceanogr., 48, 159-178, 2001.

Sinha, B., Topliss, B., and Harle, J.: Eastward propagating surface anomalies at ocean gyre boundaries, J. Geophys. Res., 109, doi:10.1029/2004JC002393, 2004.

Smith, P. C., Houghton, R. W., Fairbanks, R. G., and Mountain, D. G.: Interannual variability of boundary fluxes and water mass properties in the Gulf of Maine and on Georges Bank 1993-1997, Deep-Sea Res. II, 48, 37-70, 2001.

Stommel, H.: The Gulf Stream, Cambridge University Press, London, 1958.

Warner, A. J. and Hays, G. C.: Sampling by the continuous Plankton Recorder survey, Progr. Oceanogr., 34, 237-256, 1994.

Wyatt, T. and Horwood, J.: Model which generates red tides, Nature, 244, 238-240, 1973. 